\title{
УТИЦАЈ ИНТЕРНЕТ САДРЖАЈА НА ОДЛУКУ ТУРИСТЕ О ПОСЕТИ ДЕСТИНАЦИЈЕ КУЛТУРНОГ ТУРИЗМА
}

\author{
Сандра Драмићанин ${ }^{1}$, Бранислав Санчанин ${ }^{2}$
}

\begin{abstract}
Сажетак
Култура представља важан елемент туристичког производа једне дестинације, а туризам апарат подмиривања различитих културних потреба туриста. Веза културе и туризма доприноси подршци сектора културе, иновативности, креативности, имиџу дестинације и социјалној повезаности између туриста и локалног становништва. У данашње време немогуће је замислити функционисање туризма без интернета. Представљање културне понуде дестинације путем интернета је велики изазов и захтева изузетну посвећеност. Предмет истраживања овог рада чини утицај интернет садржаја на одлуку туристе о дестинацији културног туризма коју ће изабрати. Циљ истраживања је утицај интернет садржаја везаног за културни туризам дестинације на туристе и могућности привлачења туриста да посете дестинацију на основу прегледаног интернет садржаја. У истраживању је учествовало 165 испитаника који су посетили неку од дестинација које се баве културним туризмом на територији Републике Србије. Резултати истраживања показују да виши ниво квалитета интернет садржаја позитивно утиче да туриста одабере одређену дестинацију културног туризма за путовање и да интернет садржај у смислу ефикасности информација, интерактивности и практичности има значајно позитиван утицај на намере туриста да посете дестинацију културног туризма.
\end{abstract}

Кључне речи: културни туризам, интернет садржај, дестинација

1 Факултет за хотелијерство и туризам у Врњачкој Бањи, Универзитет у Крагујевцу, e-mail: sandradramicanin@hotmail.com

2 Факултет за менаџмент у Сремским Карловцима, Универзитет „Унион-Никола Тесла“ у Београду, e-mail: branislav.sancanin@famns.edu.rs 


\title{
INFLUENCE OF INTERNET CONTENT ON TOURISTS` DECISION TO VISIT A CULTURAL TOURISM DESTINATION
}

\begin{abstract}
Culture is an important element of a destination tourist product, and tourism is an apparatus for meeting the various cultural needs of tourists. The relationship between culture and tourism contributes to the support of the cultural sector, innovation, creativity, the image of the destination and the social connection between tourists and the local population. Nowadays, it is impossible to imagine the functioning of tourism without the Internet. Presenting the cultural offer of the destination via the Internet is a great challenge and requires exceptional commitment. The subject of research of this paper is the influence of Internet content on the decision of the tourists about the destination of cultural tourism they will choose. The aim of the research is to influence the internet content on tourists related to the cultural tourism of the destination and the possibility of attracting tourists to visit the destination based on the reviewed Internet content. The research involved 165 respondents who visited one of the cultural tourism destinations from the territory of the Republic of Serbia. The results of the research show that a higher level of quality of Internet content has a positive effect on tourists choosing a certain cultural tourism destination for travel and that Internet content in terms of information efficiency, interactivity and practicality has a significant positive impact on tourists' intentions to visit cultural tourism destination.
\end{abstract}

Keywords: cultural tourism, internet content, destination

\section{УВОД}

Туризам представља делатност која се интензивно ослања на информације, па развој дестинација све више зависи од могућности праћења и прилагођавања савременим трендовима и брзом адаптирању и способностима владања новим технологијама. Интернет садржај туризму пружа различите маркетиншке погодности и таргетирано пословање које значајно утиче на одлуке туриста. Савремени туристи своје путовање почињу отварањем интернет страница везаних за атрактивна места и потенцијалне дестинације. Проучавањем њиховог садржаја добијају информације о 
дестинацији, смештајним капацитетима, врсти превоза којом могу доћи до дестинације, атрактивностима и местима које током путовања треба посетити како би доживљај и искуство били употпуњени.

Основу културног туризма чини задовољење потреба туриста да посете културни локалитет, учествују у културној активности и доживе аутентично и незаборавно искуство. Широка палета различитих активности ове врсте туризма чини да се туристи на свакој дестинацији осећају добродошло и пожељно од стране локалних заједница.

Популарност културног туризма се све више повећава и његове стопе раста премашују светски просек. У томе помажу персонализован садржај, кратки видео снимци који приказују реалност културних дестинација, интерактивни снимци и виртуелна стварност. Сви они значајно мењају досадашње схватање туризма. Из годинеу годину се повећава број независних интернет сајтова везаних за културни туризам који пружају савете туристима, пре и у току путовања, уз могућност остављања информација о искуствима и доживљајимасадестинације.Туристи користемапеипромотивнепубликације како би прикупили информације о специфичним културним локацијама, па интернет садржај постаје све квалитетнији, визуелнији и атрактивнији. Ипак, туристи не желе само да прикупљају информације, већ желе да оставе своја искуства и доживљаје са културних дестинација у виду блогова, влогова и других врста кратких видео снимака, запажања и коментара.

Анализом интернет садржаја и трендова, сегментацијом тржишта, праћењем жеља и потреба туриста (нове генерације туриста су уско повезане са технологијом и интернетом), као и схватањем које су информацијепресудне за туристе (како би се направио ефикасан маркетиншки алат), уз континуирано упоређивање са конкуренцијом и анализом њихових пословних корака, предузећа која се баве културним туризмом, а и читаве дестинације културног туризма, могу унапредити свој положај на туристичкој мапи света и одредити будуће правце раста и развоја. Развој и унапређење квалитета интернет садржаја који се бави културним туризмом и дестинацијма културног туризма представљају кључ диференцијације дестинације у односу на конкуренте. 


\section{ПРЕГЛЕД ЛИТЕРАТУРЕ}

\section{Културни туризам}

Култура је суштински аспект друштвеног постојања и развоја. Разни изуми, очување и промоција вековне културне баштине су незамењиви катализатори развоја дестинације (Sančanin \& Dramićanin, 2019). Културни туризам означава кретање људи које је узроковано културним атракцијама, с намером сакупљања нових информација и искустава како би задовољили своје културне потребе (Richards, 1999), за уметничким и културним турама, путовањима на фестивале и друге културне догађаје, обиласком споменика и историјских места, путовањима ради уметности или ходочашћа (WTO, 2019).

Културни туризам је препознат као одрживи облик туризма који помаже у регенерацији урбанихсредина, очувању и промоцији националних културних баштина и традиције, у осигуравању бољег стандарда средине на којој се развија (Dumond et al., 2007). Културни туризам игра велику улогу у укупним туристичким кретањима. Он помаже при дефинисању културног наслеђа и културне традиције једне туристичке дестинације. Културна баштина је веома важна, јер може привући туристе из различитих култура и религија (Munsters, 2004). Кроз посете туристичкој дестинацији, културни туриста осећа и види културна богатства кроз разгледање архитектонских грађевина, музеја, историјских градова који одишу споменичким и традиционалним духом (Russo, 2002).

Различити начини живота, потребе и навике производе различите културне стилове и методе њиховог задовољења (Leask, 2010). Примарна потреба да се посети културна дестинација задовољава потребу туристе да учествује у културном животу локалитета који је посетио на начин што посећује изложбе, фестивале, концерте, музеје, споменике и историјска места (Richards, 2005). 3 а специјализоване културне туристе култура има примарни значај, а културне активности најснажнији утицај на избор дестинације. Сврха њиховог путовања је посета дестинације, у потреби за разумевањем културе простора или локалитета или потрага за одређеном врстом уметности. Туристи се у дестинације културног туризма привлаче материјалним и нематеријалним атрактивностима, док туристима након боравка на дестинацији остаје само нематеријално искуство (Angley et al., 2014).

Културни туризам знаменитостима и манифестацијама, духом и виталношћу привлачи туристе и на тај начин доноси дестинацијама бројне бенефите: побољшање изгледа и имиџа града, појачање препознатљивости града на светској културној карти, унапређење културног развоја, развој 
културног (манифестационог) туризма, културну регенерацију (Đukić \& Todorović, 2008). Елементи упознавања и откривања града имају изузетну чар за посетиоце. Новине, искуство и доживљаји које савремени туристи траже налазе се у дестинацијама културног туризма.

\section{Процес доношења одлука}

Процес доношења одлука о путовању је много сложенији од процеса одлучивања о материјалним добрима (Park et al., 2013), тако да постоји велики број теоријских модела о процесу доношења одлуке о дестинацији путовања (Kotler \& Keller, 2017, Kardes et al., 2011). Одабир најпогодније дестинације, начина путовања и смештаја је процес који троши време и труд (Hsu et al., 2012). Како се људи све више фокусирају на квалитет туристичког искуства, тражња за отвореним информацијама у туризму постаје интензивна (Wu et al., 2014). Одлука о одласку на путовање проистиче из жеље туристе за посетом одређене дестинације, одмором, авантуром или разонодом (Živković \& Brdar, 2018). Процес доношења одлуке о дестинацији путовања приказан је на слици 1.

Слика 1. Процес доношења одлуке о дестинацији путовања

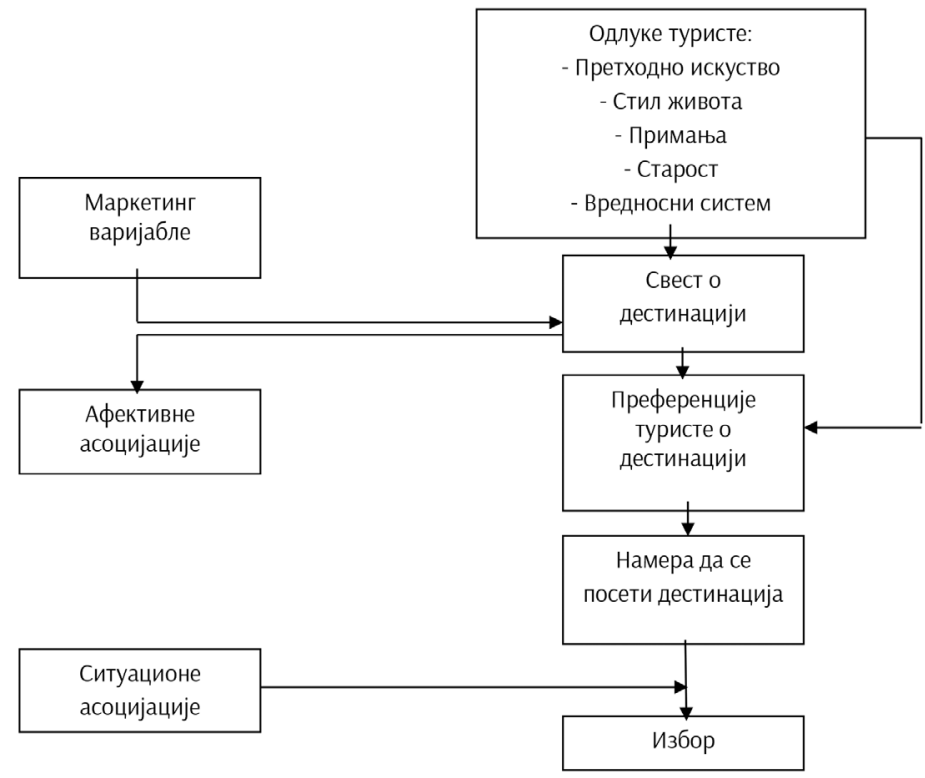

Извор: Woodside, A., Lysonski, S. (1989). A General Model Of Traveler Destination Choice. Journal of Travel Research, 27, p. 11. 
Иако мотивација покреће на акцију и води до задовољења потреба, прецизнији филтер избора је преференција туристе. Преференције су специфичније од мотива и приказују се кроз то где туриста путује и шта на дестинацији ради (Smith et al., 2010). Од изузетне је важности да се код процеса доношења одлуке препознају тзв. микро моменти (Үoо et al., 2010). Први моменат је тзв. dreaming фаза кад туриста бира дестинацију за одмор, потом следи планирање: туриста зна дестинацију, али треба да изабре хотел и остале активности на дестинацији, затим долази упоређивање цена на различитим сајтовима и резервисање смештаја и на крају, локално претраживање на самој дестинацији: куда отићи, шта све видети и доживети, коме се обратити у локалној средини sa обилазак дестинације и слично (Law et al., 2009).

У данашње време, највећи број туриста се окреће интернету у потрази за информацијама које му помажу приликом доношења одлуке о дестинацији путовања (Petan, 2008). Online прегледи засновани су на профилима туриста и њиховим утврђеним преференцијама и саставни су део формулисања преференција и утицаја на будуће резервације (Baka, 2016). Истраживање је показало да се око 95\% туриста у свету информише путем интернета, око 93\% туриста посећује web сајтове у циљу претраживања туристичких дестинација (Mamaghani, 2009). У циљу минимизирања несигурности приликом online претраживања, туристи се све више ослањају на препоруке других корисника ради сигурнијег доношења коначне одлуке у коју дестинацију ће отпутовати (Thao \& Swierczek, 2008). Према резултатима истраживања које су спровели Liu \& Park (2015) 83\% туриста користи интернет у фази планирања путовања, пре коначно донете одлуке. У туристичком контексту, препоруке туриста путем Tripadvisor-a, Booking.com-a, утичу на одлуке других путника о различитим аспектима њихових путовања, нпр. избор туристичке дестинације, смештај и атракције за посету (Pantano et al., 2017). Без обзира што су неки истраживачи указали да су многи прегледи лажни или да су претерано позитивни или негативни, туристи перципирају online прегледе као поузданији од садржаја који пружају званичне web странице дестинације (Fotis at al., 2012).

Бројни интернет алати омогућили су брже доношење одлуке туристе о дестинацији путовања, на тај начин што су олакшали приступ информацијама и резервисање смештаја, авионских карата и других туристичких услуга (De Carlos et al., 2015). Дошло је и до све шире употребе разноврсних SoLoMo (Social-Location-Mobile based applications) апликација које су туристима олакшале процес доношења одлуке (Kim \& Connolly, 2012). Клијенти могу да одаберу оне атрибуте и начин путовања који њима одговарају, а платформе 
(апликације) ће аутоматски на бази унетих критеријума формирати маршуту и приказати одговарајуће информације о потенцијалним дестинацијама за путовање и на тај начин помоћи туристи и убрзати доношење одлуке о дестинацији путовања.

\section{Утицај интернет садржаја}

Развој информационих технологија остварује изузетан утицај на свакодневни живот савременог човека. Управо захваљујући томе повезивање људи постало је једноставно и брзо, а информације лако доступне у великим количинама. Уједно је размена информација између понуде и тражње у туризму почела да се одвија интерактивно у реалном времену (Chung \& Buhalis, 2008). Интернет уз мултимедијални садржај пружа могућност покривености у целом свету и важно средство промоције и дистрибуције туристичких производа, осносно услуга (Rodriguez Vazquez et al., 2015).

Мноштво информација, које је на располагању на интернету, омогућава туристима да сами трагају за најразноврснијим понудама туристичких дестинација (Eskelsen et al., 2009). Док се интернет, сам по себи, са скоро бесплатним приступом и стандардизованим техничким знањем не може сматрати извором конкурентске предности, оно што значајно утиче на стицање исте, јесте online видљивост, односно информације које се налазе у врху листе резултата на претраживачима приликом претраге туристичких садржаја (Smithson, et al., 2011).

Суштина коришћења интернет садржаја је успостављање односа и комуникације између туриста који су користили услуге и производе дестинације и потенцијаних туриста. Интернет сајтови попут Booking-a, Tripadvisor-a, Expedia-e, Trivago-a, Airbnb-a једни су од најпосећенијих сајтова на којима туристи траже информације о потенцијалним дестинацијама. Упоредо, информације прикупљају са Facebook, Twitter, Instagram, Google +, Pinterest налога различитих корисника уз праћење блогова са путовања. Интернет као популаран извор за прикупљање информација о дестинацији, активностима, природним и антропогеним атрактивностима, хотелима, ресторанима, кафићима, пружа могућност да се утиче на потенцијалног туристу позитивно или негативно (Volo, 2010). Слика одредишта и искуство путника који су посетили дестинацију играју кључну улогу у одлуци о томе где путовати ( $\mathrm{Li} \&$ Wang, 2011; Choi et al., 2007). Корисници интернет садржаја више нису пасивни примаоци информација о дестинацијама, они данас могу да комуницирају са ауторима тих информација и са другим корисницима истих (Cao et al., 2017). 
Разумевање какве бенефите доноси квалитетан и адекватан садржај, један је од највећих изазова са којим се дестинације суочавају. Креатори интернет садржаја морају да разумеју ефективност друштвеног умрежавања ради стицања повољне маркетиншке позиције и лакшег комуницирања са туристима. Уколико је интернет садржај неадекватан, непримерен, непотпун или располаже нетачним информацијама туристи ће га заобићи (Milano et al. 2011). Да би интернет садржај имао ефекта неопходно је да 25-50\% стално запослених радника ефикасно води и управља кампањом интернет садржаја који представља предузеће у туризму или дестинацију (Turner, 2012).

Брза еволуција информационих технологија мотивише туристе да пре саме донете одлуке о путовању прегледају цео процес путовања, а туристима који сувећ били на таквом путовању да поделе своје утиске и доживљаје (Kipper \& Rampolla, 2013). Online платформе које пружају информације о локацијама интересантним за разгледање, о смештају, ресторанима, саобраћају, забави и шопингу морају да одржавају ажурне и тачне информације о популарним туристичким дестинацијама и да пружају корисне туристичке информације које су у складу са преференцијама туристима (Xiaolong et al., 2016). На пример, систем под називом PlanTour користи приступ аутоматског планирања како би генерисао вишедневни план са најрелевантнијим тачкама интересовања у некој дестинацији која се посећује. Систем прикупља информације о корисницима и тачкама интересовања, а затим користи аутоматизовани планер који формира квалитетне туристичке планове на бази оцена корисника на друштвеним мрежама. Користи се интелигентни систем који комбинује генерисано знање са ефикасним аутоматизованим техникама (Cenamor et al., 2017). Специјализовани блогови пружају бесплатне web просторе предузећима у циљу пласмана туристичких понуда и омогућавају online посетиоцима да пренесу своја јединствена искуства и доживљаје са путовања. Блогови су део online заједнице, коју чине групе посетилаца које имају заједничка интересовања и размењују искуства путем форума или chat-a (Sigala et al, 2007).

Интернет садржај има специфичну карактеристику, а то је могућност константног мењања и прилагођавања, па је оптимизација претраживача неопходан алат који помаже побољшању видљивости странице једне туристичке дестинације (Terrelonge, 2011). На тај начин дестинација може привући потенцијалне туристе да је посете. Глобална туристичка индустрија се креће у правцу максималног коришћења интернет садржаја како би промовисала своју понуду. Умрежавање информација путем интернета расте великом брзином, па је неопходно да се туристичке дестинације прилагоде како би успеле. 


\section{МЕТОДОЛОГИЈА}

\section{Дизајнирање упитника и прелиминарно тестирање}

За потребе истраживања формиран је упитник који се састоји из два дела. Први део обухвата демографске карактеристике, број путовања у дестинације културног туризма, извор информација о њима и учесталост коришћења и врсту интернет садржаја везаних за културни туризам. Други део упитника је главни део целокупног истраживања. Упитник садржи питања везана за интернет садржај везан за културни туризам и одлуке туриста о дестинацији за путовање, прилагођен је на основу постојећег упитника који су конструисали Сaо, Yu \&Tian (2017). Четири ставке мере намеру туристе да донесе одлуку везано за дестинацију путовања, а 25 ставки мере карактеристике интернет садржаја везаног за културни туризам. Наведене ставке су подељене у 8 подкатегорија: покривеност (3 питања), интерактивност (3 питања), дељивост (3 питања), повезаност (3 питања), квалитет (3 питања), практичност (3 питања), транспарентност информација (3 питања) и ефикасност информација (4 питања). Испитници су свој став изражавали оценом од 1-5, где је 1- апсолутно неслагање, а 5- апсолутно слагање. Упитник су попуњавали online, а услов је био да су посетили неку од дестинација које се баве културним туризмом на територији Републике Србије.

Прелиминарно тестирање спроведено је 2018. године, на узорку од 92 испитаника (истраживање је делом изведено online, а делом у личном контакту са испитаницима), од којих је 85 било валидно, па је важећа стопа одговора 92,39\%. Резултати испитивања поузданости програма SPSS 21 показују да целокупан упитник има високу поузданост, Cronbach Alpha коефицијент износи 0.922. Након тога форматиран је коначан упитник у електронској форми.

\section{Селекција узорка и прикупљање података}

Истраживање је спроведено током јула и августа 2020. године. Од укупно 200 испитаника који су посетили неку дестинацију културног туризма у Србији је затражено да попуне упитник. Упитник је попунио 171 испитаник (85,5\%). Од тог броја укупно је било валидно 165 упитника, што је 96,49\%. 
Демографске карактеристике испитаника приказане су у табели 1.

Табела 1. Демографска структура испитаника

\begin{tabular}{|l|l|c|c|}
\hline $\begin{array}{l}\text { Демографске } \\
\text { карактеристике }\end{array}$ & Категорија & Фреквенција & Проценат \\
\hline \multirow{4}{*}{ Пол } & Мушки & 56 & $33,94 \%$ \\
\hline & Женски & 109 & $66,06 \%$ \\
\hline \multirow{4}{*}{$\begin{array}{l}\text { Старосна } \\
\text { структура }\end{array}$} & $18-20$ година & 9 & $5,45 \%$ \\
\cline { 2 - 4 } & $21-30$ година & 64 & $38,79 \%$ \\
\cline { 2 - 4 } & $31-40$ година & 26 & $15,76 \%$ \\
\cline { 2 - 4 } & $41-50$ година & 34 & $20,61 \%$ \\
\cline { 2 - 4 } & $51-60$ година & 18 & $10,91 \%$ \\
\cline { 2 - 4 } & Више од 60 година & 14 & $8,48 \%$ \\
\hline \multirow{4}{*}{$\begin{array}{l}\text { образовна } \\
\text { структура }\end{array}$} & Средња школа & 40 & $24,24 \%$ \\
\cline { 2 - 4 } & Виша/струковна школа & 65 & $13,33 \%$ \\
\cline { 2 - 4 } & Висока школа/факултет & 35 & $21,21 \%$ \\
\cline { 2 - 4 } & Мастер/магистарске студије & 3 & $1,82 \%$ \\
\cline { 2 - 4 } & Докторске студије & & \\
\hline
\end{tabular}

Извор: Обрада аутора

Број путовања у дестинације културног туризма, извор информација о дестинацијама и врста и учесталост коришћења интернет садржаја налази се у табели 2. 
Табела 2. Број путовања, извор информација и учесталост коришћења и врста интернет садржаја

\begin{tabular}{|c|c|c|c|}
\hline Варијабле & Категорија & Фреквенција & Проценат \\
\hline \multirow{4}{*}{$\begin{array}{l}\text { Број путовања } \\
\text { током године } \\
\text { у дестинацију } \\
\text { културног } \\
\text { туризма }\end{array}$} & Једном & 72 & $43,64 \%$ \\
\hline & 2-5 пута & 75 & $45,45 \%$ \\
\hline & Више од пет пута & 12 & $7,27 \%$ \\
\hline & Не путујем & 6 & $3,64 \%$ \\
\hline \multirow{4}{*}{$\begin{array}{l}\text { Извор } \\
\text { информација о } \\
\text { дестинацијама } \\
\text { културног } \\
\text { туризма }\end{array}$} & $\begin{array}{l}\text { Препорука пријатеља, } \\
\text { познаника и родбине }\end{array}$ & 23 & $13,94 \%$ \\
\hline & $\begin{array}{l}\text { Интернету (сајтови, } \\
\text { друштвене мреже, блогови) }\end{array}$ & 102 & $61,82 \%$ \\
\hline & $\begin{array}{l}\text { Туристичка агенција и } \\
\text { туроператер }\end{array}$ & 23 & $13,94 \%$ \\
\hline & Брошуре и проспекти & 17 & $10,30 \%$ \\
\hline \multirow{5}{*}{$\begin{array}{l}\text { Учесталост } \\
\text { коришћења } \\
\text { интернет } \\
\text { садржаја везаног } \\
\text { да културне } \\
\text { дестинације }\end{array}$} & Једном дневно & 86 & $52,12 \%$ \\
\hline & Једном недељно & 42 & $25,45 \%$ \\
\hline & Једном месечно & 23 & $13,94 \%$ \\
\hline & Неколико пута годишње & 9 & $5,45 \%$ \\
\hline & Никада & 5 & $3,03 \%$ \\
\hline \multirow{7}{*}{$\begin{array}{l}\text { Врста интернет } \\
\text { садржаја } \\
\text { коју туристи } \\
\text { претражују }\end{array}$} & $\begin{array}{l}\text { Лично искуство предходних } \\
\text { путника }\end{array}$ & 37 & $22,42 \%$ \\
\hline & Информације о ценама & 21 & $12,73 \%$ \\
\hline & Туристичке водиче и мапе & 22 & $13,33 \%$ \\
\hline & $\begin{array}{l}\text { Значајне локалитете које } \\
\text { треба посетити }\end{array}$ & 27 & $16,36 \%$ \\
\hline & Смештај & 31 & $18,79 \%$ \\
\hline & $\begin{array}{l}\text { Околна места и информације } \\
\text { о саобраћају }\end{array}$ & 18 & $10,91 \%$ \\
\hline & Места за забаву & 9 & $5,45 \%$ \\
\hline
\end{tabular}

Извор: обрада аутора 


\section{РЕЗУЛТАТИ ИСТРАЖИВАЊА}

Резултати корелационе анализе између одлуке туристе о дестинацији путовања и 8 фактора који представљају карактеристике интернет садржаја налазе се у табели 3. Одлука туристе о дестинацији путовања и осам фактора интернет садржаја имају позитивне корелације $(p<0.01)$ : квалитет $(r=0.673)$, ефикасност информација ( $r=0.603)$, интерактивност $(r=0.595)$, практичност $(r=0.565)$, покривеност $(r=0.532)$, дељивост $(r=0.478)$, повезаност $(r=0.431)$ и транспарентност информација $(r=0.398)$.

Табела 3. Коралациона анализа

\begin{tabular}{|l|l|r|r|r|r|r|r|r|r|r|}
\hline \multicolumn{2}{|l|}{} & $\mathbf{1}$ & $\mathbf{2}$ & $\mathbf{3}$ & $\mathbf{4}$ & $\mathbf{5}$ & $\mathbf{6}$ & $\mathbf{7}$ & $\mathbf{8}$ & $\mathbf{9}$ \\
\hline $\mathbf{1}$ & $\begin{array}{l}\text { Одлука туристе } \\
\text { одестинацији } \\
\text { путовања }\end{array}$ & 1 & & & & & & & & \\
\hline $\mathbf{2}$ & Покривеност & 0.532 & 1 & & & & & & & \\
\hline $\mathbf{3}$ & Интерактивност & 0.595 & 0.482 & 1 & & & & & & \\
\hline $\mathbf{4}$ & Дељивост & 0.478 & 0.303 & 0.436 & 1 & & & & & \\
\hline $\mathbf{5}$ & Повезаност & 0.431 & 0.317 & 0.451 & 0.432 & 1 & & & & \\
\hline $\mathbf{6}$ & Квалитет & 0.673 & 0.254 & 0.444 & 0.440 & 0.505 & 1 & & & \\
\hline $\mathbf{7}$ & Практичност & 0.565 & 0.331 & 0.399 & 0.361 & 0.434 & 0.458 & 1 & & \\
\hline $\mathbf{8}$ & $\begin{array}{l}\text { Транспарентност } \\
\text { информација }\end{array}$ & 0.398 & 0.323 & 0.405 & 0.332 & 0.521 & 0.372 & 0.410 & 1 & \\
\hline $\mathbf{9}$ & $\begin{array}{l}\text { Ефикасност } \\
\text { информација }\end{array}$ & 0.603 & 0.404 & 0.502 & 0.430 & 0.446 & 0.531 & 0.492 & 0.399 & 1 \\
\hline
\end{tabular}
$\mathrm{p}<0.01$

Извор: обрада аутора

У циљу даље анализе односа између карактеристика интернет садржаја и одлуке туристе о дестинацији путовања коришћена је вишеструка регресиона анализа, где 8 карактеристика интернет садржаја представљају независне варијабле, а одлука туристе зависну варијаблу. Табела 4. показује резултате регресионе анализе. 
Табела 4. Регресиона анализа

\begin{tabular}{|l|c|c|c|c|}
\hline & $\beta$ & $\mathbf{R}$ & Adjust $^{2}$ & $\mathbf{p}$ \\
\hline Квалитет & 0.288 & 0.741 & 0.539 & 0.000 \\
\hline Интерактивност & 0.209 & 0.723 & 0.515 & 0.000 \\
\hline Ефикасност информација & 0.254 & 0.736 & 0.535 & 0.005 \\
\hline Практичност & 0.123 & 0.712 & 0.498 & 0.010 \\
\hline Покривеност & 0.085 & 0.698 & 0.465 & 0.000 \\
\hline
\end{tabular}

Извор: обрада аутора

Резултати показују да код 5 од укупно 8 карактеристика постоји позитивна и значајна повезаност, што значи да тих 5 карактеристика (квалитет, интерактивност, ефикасност информација, практичност и покривеност) позитивно делују на одлуку туристе о дестинацији путовања, док код три карактеристике (дељивост, повезаност, транспарентност информација) коефицијент регресије није значајан.

\section{ДИСКУСИЈА}

Интернет садржај игра све важнију улогу као извор информација за туристе (Xiang \& Ulrike, 2010). Дељење доживљаја путем интернет садржаја се јавља као вредна интеракција друштвене и емоционалне подршке и као важан извор информација за доношење одлука о одмору (Munar \& Steen-Jacobsen, 2014). Све веће ослањање на интернет као извор информација приликом доношења одлука о туристичким путовањима, ствара потребу истраживања информација које се налазе на интернету и њихових карактеристика (Sparks \& Browning, 2011).

Интернет садржаји туристичких дестинација се значајно разликују у смислу језичких карактеристика, семантичких карактеристика, осећаја, рејтинга, корисности, као и односа између ових особина (Xiang et al., 2017) и на различите начине утичу на туристе приликом доношења одлуке о дестинацији културног туризма.

Негативни коментари, односно негативне карактеристике и непоузданост интернет садржаја чине комплетан утисак о дестинацији негативним, 
док позитивни подстичу потребу и повећавају намеру туристе да резервишу путовање (Torres, 2017). Једна од све већих употреба и користи интернет садржаја огледа се у ангажовању стварних и потенцијалних посетилаца (Romolini et al, 2020). Ангажовање клијената, како би промовисали одређену дестинацију, олакшава утицај карактеристика интернет садржаја и привлачи туристе (Harrigan, et al., 2017). Интернет садржај који је генерисао туриста представља важан нови информациони медиј за друге, потенцијалне туристе током читавог животног циклуса куповине, трансформишући начин на који посетиоци процењују, бирају дестинације културног туризма и деле искуства о овој врсти туризма (Yue et al., 2017).

Интернет садржај везан за културни туризам одиграо је кључну улогу у маркетингу дестинација, а њихово брзо ширење трансформисало је начин на који се приступа информацијама како утичу на туристе (Pantano et al., 2014). Туристи могу приступити овим информацијама како би олакшали процес доношења одлука. Ове информације су доступне на мрежи и генеришу тзв. отворене податке (Pantano, et al., 2017). Интернет садржај шири своје могућности пружањем разноврсног портфолија уграђених апликација како би задовољили потребе корисника за новим искуствима (Tung et al., 2014), укључујући коментаре о прошлим искуствима и препоруке за будуће резервације (Turban et al., 2015). Овакве карактеристике интернет садржаја позитивно утичу на одлуку туристе о дестинацији путовања (Pirroli, 2016).

О утицају интернета и његовог садржаја на понашање и одлуку туриста истраживали су Tierney (2000) и Buhalis \& Licata (2002) који су дошли до истог закључка: карактеристике интернет садржаја имају значајан утицај на понашање и одлуке туристе. Valdez (2012) у свом истраживању испитује утицај Hypertext-a као елемента интернет садржаја на одлуку туриста и долази до закључка да постоји позитивна повезаност. Үи (2013) наводи три битне карактеристике интернет садржаја: интерактивни, мултимедијални и хипертекст, који разликује концепт интернет садржаја од традиционалних и нових медија и доприноси лакшем сналажењу туриста и бржем проналажењу неопходних информација. У свом истраживању Jiao et al. (2013) наводе да карактеристике интернет садржаја као што су квалитет, ефикасност и транспарентност имају највећи утицај на туристе, а Cao et. Al (2017) дошли су до резултата који се усаглашавају са резултатима овог рада. 


\section{ЗАКЉУЧАК}

Велика количина информација која је на располагању путем интернет садржаја, омогућава туристима да сами трагају за интересантним дестинацијама културног туризма, занимљивим местима, повољним ценама. Туристима велики значај представља искуство подељено на интернету од стране путника који су већ посетили одређену дестинацију културног туризма, одсели у неком хотелу, посетили музеј или други културни локалитет или користили услуге туристичког предузећа. 36ог свакодневног напретка интернета, долази до мењања облика и карактеристика његовог садржаја, креативних процеса, механизама дистрибуције и промоције као и образаца дељења тог интернет садржаја. Интернет садржаји служе за проналажење већег броја тачних, прецизних, ажурираних података о једном месту. Тако да туриста и пре путовања зна шта може да, очекује на дестинацији и да олакшано, на основу добијених информација донесе одлуку о дестинацији путовања. Ипак, с обзиром на новитет теме, чини се да је литература оскудна и овај рад сугерише неопходност дубљег проучавања употребе интернет садржаја у културном туризму, ради привлачења већег броја туриста.

У данашње време компаније које се баве културним туризмом, треба да обрате пажњу која је то информациона технологија и какве су њене карактеристике које ће привући што више туриста, које апликације треба користити и какве могућности понудити потенцијалним посетиоцима. Дестинације културног туризма прво треба да истраже потребе туриста и какво искуство они желе да доживе, затим да испоруче технологију која ће најбоље испунити њихове жеље, што ће олакшати процес доношења одлука.

\section{ЛИТЕРАТУРА}

1. Angley, D., O'Byrne-Prior, J., O'Connor, N. (2014). Visitor Attractions: The Future of Social Media in Heritage, Urban and Natural Tourism. International Hospitality and Tourism Student Journal, 6(4), 326-340.

2. Baka, V. (2016). The becoming of user-generated reviews: Looking at the past to understand the future of managing reputation in the travel sector. Tourism Management, $53,148-162$.

3. Buhalis, D., Licata, M. C. (2002). The future e-tourism intermediaries. Tourism Management, 23 (3), 207-220. 
4. Cao, Q., Yu, B., Tian, T.X.X. (2017). The Effect of Social Media on Tourism Consumer Adoption Intention: Evidence from Urumqi. Journal of Accounting \& Marketing, 6(1), 219-229.

5. Cenamor, I., De la Rosa, T., Nunez, S., Borrajo, D. (2017). Planning for Tourism Routes Using Social Networks. Expert Systems with Applications, 69, 1-9.

6. Choi, S., Lehto, X.Y., Morrison, A.M. (2007). Destination image representation on the web: content analysis of Macau travel related websites. Tourism Management, 28, 118-129.

7. Chung, Y., Buhalis, D. (2008). Information Needs in Online Social Networks. Information Technology \& Tourism, 10(4), 267-281.

8. De Carlos, P., Araujo, N., Fraiz, J. (2015). The New Intermediaries of Tourist Distribution: Analysis of Online Accomodation Booking Sites. The International Journal of Management Science and Information Technology, 25, 39-58.

9. Dumont, E., Ruelle, C., Teller, G. (2007). Pro-active management of The Impact of Cultural Tourism Upon Urban Resources and Economies, Integrating and strengthening the European Research Area Activity,6th Framework Programme of Research.

10. Đukić, V., Todorović, M. (2008). Kulturni turizam- most između kulturne i turističke politike, Zbornik Fakulteta dramskih umetnosti, 13-14, 112-129.

11. Eskelsen, G., Marcus, A., Ferree, W. (2009). The Digital Economy Fact Book. Washington D. C.: The Progress \& Freedom Foundation.

12. Fotis, J., Buhalis, D., Rossides, N. (2012). Social Media Use and Impact during the Holiday Travel Planning Process. Information and Communication Technologies in Tourism, $10,13-24$.

13. Harragan. P., Evers., U., Miles. M., Daly, T. (2017). Customer engagement with tourism social media brands. Tourism Management, 59, 597-609.

14. Hsu, F. M., Lin, Y. T., Ho, T. K. (2012). Design and implementation of an intelligent recommendation system for tourist attractions: The integration of EBM model, bayesian network and google maps. Expert Systems with Applications, 39(3), 3257-3264.

15. Jiao, Y.B., Gao, J, Yang, J. (2013). Factors influencing consumers' adoption of social media- a theoretical model and its empirical research. Journal of Shanxi Finance Economics, 35, 43-55.

16. Kardes, F. R., Cline, T. W., Cronley, M. L. (2011). Consumer behaviour: Science and practice. China: South-Western.

17. Kim, J., Connolly, D. (2012). Hospitality in the age of customer empowerment. First Annual Customer Engagement Technology Study. Randolph, NJ: Hospitality Technology. 
18. Kipper, G., Rampolla, J. (2013). Augmented Reality: An Emerging Technologies Guide to $A R$, Waltham, MA, Elsevier.

19. Kotler, P., Keller, K. (2017). Marketing Management, Prentice Hall, Saddle River.

20. Law, R., Leung, R., Buhalis, D. (2009). Information Technology Applications in Hospitality and Tourism: A Review of Publications from 2005 to 2007, Journal of Travel \& Tourism Marketing, 26(5), 599-623.

21. Leask, A. (2010). Progress in visitor attraction research: Towards more effective management, Tourism Management, 31 (2), 155-166.

22. Li, X., Wang, Y. (2011). China in the eyes of Western travelers as represented in travel blogs, Journal of Travel \& Tourism Marketing, 28(7), 689-719.

23. Liu, Z., Park. S. (2015). What makes a useful online review? Implication for travel product websites. Tourism Management, 47, 140-151.

24. Mamaghani, F. (2009). Impact of E-Commerce on Travel and Tourism: An Historical analysis. International Journal of Management, 26, 365-386.

25. Milano, R., Baggio, R., Piatelli, B. (2011). The effects of online social media on tourism websites, 18th International conference on information technology and travel \& tourism. Inssbruk, Austria.

26. Munar, A. M., Steen Jacobsen, J.K. (2014). Motivations for sharing tourism experiences through social media. Tourism Management, 43, 46-54.

27. Munsters, W. (2004). Culture \& Tourism: merely a marriage of convenience?, Inaugural speech un the Centre of Expertise of Cultural Tourism, Zuyd University of Applied Sciences, Maastricht.

28. Pantano, E., Di Pietro, L. (2013). From e-tourism to f-tourism: Emerging issues from negative tourists' online reviews. Journal of Hospitality and Tourism Technology, 4(3), 211-217.

29. Pantano, E., Priporas, C.V., Stylos, N. (2017). You will like it!' using open data to predict tourists' response to a tourist attraction. Tourism Management, 60, 430-438.

30. Park, S., Nicolau, J. L., Fesenmaier, D. R. (2013). Assessing advertising in a hierarchical decision model. Annals of Tourism Research, 40, 260-282.

31. Pirolli, B. (2016). Travel information online: navigating correspondents, consensus, and conversation. Current Issues in Tourism, 48, 1-7.

32. Richards, G. (1999). European cultural tourism: patterns and prospects, in: Dodd, D., Van Hemel, A.-M. (eds) Planning European Cultural Tourism, Boekman Foundation, Amsterdam, 16-32.

33. Richards, G. (2005). Cultural Tourism in Europe, CAB International, Wallington, UK. 
34. Rodriguez Vazquez, C., Rodriguez Campo, L., Martinez Fernandes, V., Rodriguez Fernandez, M. (2015). The Effects of the Application of the Internet and Information and Communication Technologies in the Field of Tourism Mediation. The International Journal of Management Science and Information Technology, 27, 1-20.

35. Romolini, A., Fissi, S., Gori, E, (2020). Visitors engagement and social media in museums: evidence from Italy. International Journal of Digital Culture and Electronic Tourism, 3(1), 36-53.

36. Russo, A.P. (2002). Cultural Clusters and Tourism Development: the Challenge of Venice, Culture: A Driving Force for Urban Tourism, Institute for International Relation, Zagreb.

37. Sančanin, B., Dramićanin, S. (2019). The significance of the Representative List of the Intangible Cultural Heritage for the preservation of Serbian cultural heritage. Baština. 49, 419-431.

38. Sigala, M., Evangelos, C., Gretzel, U. (2010). Social media in Travel, Tourism and Hospitality: Theory, Practices and Cases, Surrey, Ashgate Publishing.

39. Smith, M. K., MacLeod, N. Hart Robertson, M. (2010): Key Concepts in Tourist Studies. SAGE: London.

40. Smithson, S., Devece, C.A., Lapiedra, R. (2011). Online visibility as a source of competitive advantage for small and medium-sized tourism accommodation enterprises. Service Industries Journal, 31(10), 1573-1587.

41. Sparks. A.B., Browning, V. (2011). The impact of online reviews on hotel booking intentions and perception of trust. Tourism Management, 32(6), 1310-1323.

42. Terrelongé, R. (2011). An Easy Guide to Search Engine Optimisation (SEO) \& Branding For Quick Results, Longe Distribution Inc

43. Thao, H., Swierczek, F. (2008). Internet use, customer relationships and loyalty in the Vietnamese travel industry. Asia Pacific Journal of Marketing and Logistics, 20(2), 190 210.

44. Tierney, P. (2000). Internet-based evaluation of tourism web site effectiveness: Methodological issues and survey results. Journal of Travel Research, 39 (2), 212-219.

45. Torres, R. (2017). Technology Trends \& the Future of Travel. Travel \& Tourism global impact \& issues, 1-17.

46. Tung, T., Jai, T. M., Davis Burns, L. (2014). Attributes of apparel tablet catalogs: Value proposition comparisons. Journal of Fashion Marketing and Management, 18(3), 321 337.

47. Turban, E., King, D., Lee, J. K., Liang, T. P., Turban, D. C. (2015). Social commerce: Foundations, social marketing, and advertising. In: Electronic commerce: A managerial and social networks perspective, Springer International Publishing, 309-365. 
48. Turner, J. (2012). How to use Social Media Monitoring Tools, New Jersey, Pearson's Education Ltd.

49. Valdez, R. (2012). The Role of Hypertext in Consumer Decision Making: The Case of Travel Destination Choice. Journal of Entrepreneurship, Management and Innovation. 8, 78-95.

50. Volo, S. (2010). Bloggers' reported tourist experiences: Their utility as a tourism data source and their effect on prospective tourists. Journal of Vacation Marketing, 16(4), 297-311.

51. Woodside, A., Lysonski, S. (1989). A General Model Of Traveler Destination Choice. Journal of Travel Research, 27, 8-14.

52. WTO (2019). Tourism and Culture, https://www.unwto.org/tourism-and-culture

53. Wu, C. T., Liu, S. C., Chu, C. F., Chu, Y. P., Yu, S. S. (2014). A study of open data for E. Pantano et al., Tourism Management, 60, 430-438.

54. Xiang, Z., Du, Q., Ma, Y., Fan, W. (2017). A comparative analysis of major online review platforms: Implications for social media analytics in hospitality and tourism. Tourism Management, 58, 51-65.

55. Xiang, Z., Ulrike, G. (2010). Role of social media in online travel information search. Tourism Management, 31(2), 179-188.

56. Xiaolong, H., Xiaomei, Z., Fangyan, L. (2016). Study on the cooperation of hotels and online self-service travel business based on information technology. Revista lberica de Sistemas e Tecnologias de Informaticao, 125-136.

57. Yoo, W., Lee, Y., Park, J. (2010). The role of interactivity in e-tailing: Creating value and increasing satisfaction. Journal of Retailing and Consumer Services, 17(2), 89-96.

58. Yu, T.T. (2013). Innovation of marketing communication strategy based on social media reputation. Journalism Quarterly, 3,115-120.

59. Yue, G., Barnes, S.J., Qiong, J. (2017). Mining meaning from online ratings and reviews: tourist satisfaction analysis using latent dirichlet allocation. Tourism Management, 59, 467-483.

60. Živković, R., Brdar, I. (2018). Ponašanje i zaštita potrošača u turizmu, Singidunum, Beograd. 


\section{Табела са изјавама по подкатегоријама}

\begin{tabular}{|c|c|c|}
\hline \multirow{4}{*}{1} & \multirow{4}{*}{$\begin{array}{l}\text { Одлука туристе } \\
\text { о дестинацији } \\
\text { путовања }\end{array}$} & $\begin{array}{l}\text { Увек трагам за инфомацијама о културном туризаму на } \\
\text { интернету }\end{array}$ \\
\hline & & $\begin{array}{l}\text { Интернет садржај је први извор информација када } \\
\text { тражим податке о културном туризму }\end{array}$ \\
\hline & & $\begin{array}{l}\text { Сматрам да је коришћење интернет садржаја за дељење } \\
\text { и размену информација о културном туризму корисно }\end{array}$ \\
\hline & & $\begin{array}{l}\text { Наставићу да користим интернет садржај за проналазак } \\
\text { информација о културном турзму }\end{array}$ \\
\hline \multirow{3}{*}{2} & \multirow{3}{*}{ Покривеност } & $\begin{array}{l}\text { Активно учествујем у дељењу различитог интернет } \\
\text { садржаја везаног за културни туризам }\end{array}$ \\
\hline & & $\begin{array}{l}\text { Не могу да замислим да дан проведем без коришћења } \\
\text { интернета у сврху тражења информација о културном } \\
\text { туризму }\end{array}$ \\
\hline & & $\begin{array}{l}\text { Прихватам позив пријатеља да размењујемо информаци- } \\
\text { је и занимљивости путем интернета о културном туризму }\end{array}$ \\
\hline \multirow{3}{*}{3} & \multirow{3}{*}{ Интерактивност } & $\begin{array}{l}\text { Волим да користим интернет како бих комуницирао/ла } \\
\text { са људима на тему културног туризма }\end{array}$ \\
\hline & & $\begin{array}{l}\text { Користим интернет врло често и остварујем мноштво } \\
\text { контаката везано за културни туризам }\end{array}$ \\
\hline & & $\begin{array}{l}\text { Задовољан/на сам високом интерактивношћу интернет } \\
\text { садржаја на тему културног туризма }\end{array}$ \\
\hline \multirow{3}{*}{4} & \multirow{3}{*}{ Дељивост } & $\begin{array}{l}\text { Користим интернет садржај како бих поделио/ла } \\
\text { осећања и доживљаје везане за културни туризам }\end{array}$ \\
\hline & & $\begin{array}{l}\text { Већина људи користи интернет садржај како би } \\
\text { размељивали искуства и доживљаје везане за културни } \\
\text { туризам }\end{array}$ \\
\hline & & $\begin{array}{l}\text { Желим да користим интернет садржај како бих делио/ла } \\
\text { информације у било које време, на било ком месту }\end{array}$ \\
\hline \multirow{3}{*}{5} & \multirow{3}{*}{ Повезаност } & $\begin{array}{l}\text { Интернет садржај ми омогућава доступност широком } \\
\text { спектру информација о културном туризму }\end{array}$ \\
\hline & & $\begin{array}{l}\text { Могуће је пронаћи особе које воле исте ствари везане за } \\
\text { културни туризам путем интернета }\end{array}$ \\
\hline & & $\begin{array}{l}\text { Могу се повезати са најрелевантнијим информацијама о } \\
\text { културном туризму путем интернета }\end{array}$ \\
\hline
\end{tabular}




\begin{tabular}{|c|c|c|}
\hline \multirow{3}{*}{6} & \multirow{3}{*}{ Квалитет } & $\begin{array}{l}\text { Што је интернет садржај о културном туризму } \\
\text { квалитетнији, спреман/на сам да одвојим више времена } \\
\text { како бих проучио/ла информације }\end{array}$ \\
\hline & & $\begin{array}{l}\text { Имам више воље да посећујем интернет садржај о } \\
\text { културном туризму, ако је квалитетан }\end{array}$ \\
\hline & & $\begin{array}{l}\text { Што је интернет садржај о културном туризму } \\
\text { квалитетнији, спреман/на сам да препоручим } \\
\text { пријатељима }\end{array}$ \\
\hline \multirow{3}{*}{7} & \multirow{3}{*}{ Практичност } & $\begin{array}{l}\text { Лакоћа коришћења интернет садржаја везаног за } \\
\text { културни туризам, повећава моје коришћење истог }\end{array}$ \\
\hline & & $\begin{array}{l}\text { Лакши приступ информацијама о културном туризму } \\
\text { повећава мој број посета интернет садржаја }\end{array}$ \\
\hline & & $\begin{array}{l}\text { Могућност 24-овног приступа информацијама о } \\
\text { културном туризму, повећава моје коришћење интернет } \\
\text { садржаја }\end{array}$ \\
\hline \multirow{3}{*}{8} & \multirow{3}{*}{$\begin{array}{l}\text { Транспарентност } \\
\text { информација }\end{array}$} & $\begin{array}{l}\text { Информације о културном туризму су на интернету } \\
\text { транспарентне }\end{array}$ \\
\hline & & $\begin{array}{l}\text { Разлог зашто користим интернет садржаје је доступност } \\
\text { информација о културном туризму }\end{array}$ \\
\hline & & $\begin{array}{l}\text { Што је већа транспарантност информација о културном } \\
\text { туризму, више користим интернет садржај }\end{array}$ \\
\hline \multirow{4}{*}{9} & \multirow{4}{*}{$\begin{array}{l}\text { Ефекасност } \\
\text { информација }\end{array}$} & $\begin{array}{l}\text { Када добијем релевантне информације о културном } \\
\text { туризму на основу интернет садржаја, то повећава } \\
\text { моје разумевање културног туристичког производа } \\
\text { дестинације }\end{array}$ \\
\hline & & $\begin{array}{l}\text { Може се уштедети много времена користећи интернет } \\
\text { садржај везан за културни туризам }\end{array}$ \\
\hline & & $\begin{array}{l}\text { Може се уштедети много новца, времена и енергије } \\
\text { и убрзаће се процес доношења одлуке о дестинацији } \\
\text { путовања, користећи интернет садржај везан за културни } \\
\text { туризам }\end{array}$ \\
\hline & & $\begin{array}{l}\text { Мислим да је ситуација везана за културни туризам у } \\
\text { великој мери у складу са информацијама које презентује } \\
\text { интернет садржај }\end{array}$ \\
\hline
\end{tabular}

Рад је примљен: 27. август 2020. рихваћен за објављивање: 31. август 2020.

Received: August 27, 2020. Accepted: August 31, 2020. 